УдК 616.342-002-089.844-06:617.586-002.3/.4:616.379-008.64

DOI 10.11603/2414-4533.2019.1.9908

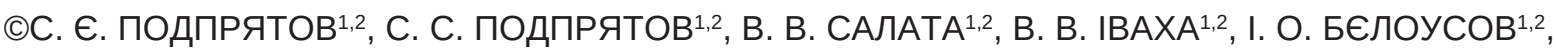
В. П. КОРЧАК ${ }^{1,2}$, І. В. САЦЮК

Київський міський центр електрозварювальної хірургії

Київська міська клінічна лікарня № $1^{2}$

\title{
Вплив ілеодуоденопластики на перебіг гнійно-некротичного ураження стопи у хворих на цукровий діабет 2 типу
}

\begin{abstract}
Мета роботи: оцінити вплив виконання ілеодуоденопластики на стан перебігу гнійно-некротичного ураження стопи у хворих на цукровий діабет 2 типу.

Матеріали і методи. Проведено аналіз результатів виконання операції на кишечнику у 21 хворого на цукровий діабет 2 типу, ускладнений гнійно-некротичним ураженням стопи. Ілеодуоденопластика є варіантом виключення дванадцятипалої кишки з проходження їжі та переміщення здухвинної кишки. Серед пацієнтів було 12 чоловіків та 9 жінок, медіана віку 63 роки, інтерквартильний розмах (IKP) 13 років, з індексом маси тіла (IMT) медіана 32,3 кг/см², IKP 8,1 кг/см². Середня тривалість цукрового діабету склала 10 років, ІКР 9 років. Отримували таблетовані глюкозознижуючі препарати 6 пацієнтів, парентерально вводили інсулін 15 хворим.

Результати досліджень та їх обговорення. Нормоглікемія без медикаментозної корекції була досягнута впродовж 3 тижнів після виконання ілеодуоденопластики у 19 пацієнтів, потребували прийому метформіну впродовж 2 місяців 2 хворі.

Висока ампутація нижньої кінцівки здійснена у 2 пацієнтів через 3 та 6 місяців після виконання ілеодуоденопластики на тлі критичної ішемії стопи. У інших пацієнтів кровотік в артеріях стопи суттєво покращився. У пацієнтів 3 діабетичною артроостеопатією та гнійним ураженням стопи високу ампутацію не виконували. В термін до 5 років рецидиву ні гіперглікемії, ні діабетичного ураження стопи не спостерігали.

Виконання ілеодуоденопластики є більш ефективним способом лікування гнійно-некротичного ураження стопи у хворих на цукровий діабет 2 типу порівняно з іншими способами.
\end{abstract}

Ключові слова: цукровий діабет 2 типу; ілеодуоденопластика; гнійно-некротичне ураження стопи.

Постановка проблеми і аналіз останніх досліджень та публікацій. Лікування, здійснене згідно з існуючими правилами, дозволяє зупинити гнійно-некротичне ураження стопи у більшості хворих на цукровий діабет 2 типу $[1,2]$.

Однак, незважаючи на дотримання всіх відомих правил, у частини пацієнтів деструктивне ураження прогресує, що приводить до необхідності реампутації, за даними метааналізу, в 19,8 \% спостережень [3], здійснення високої ампутації нижньої кінцівки в 6-78 \% спостережень [4]. Навіть досягнення успіху в лікуванні гострого ураження не гарантує від його повтору у віддаленому терміні і ніяк не дозволяє прогнозувати результат наступного лікування.

Це спонукає до безперервного пошуку більш ефективних, ніж існуючі, способів лікування гнійно-некротичного ураження стопи у хворих на цукровий діабет 2 типу [5].

Мета роботи: оцінити вплив виконання ілеодуоденопластики на стан перебіг гнійно-некротичного ураження стопи у хворих на цукровий діабет 2 типу.

Матеріали та методи. Проведений аналіз результатів обстеження та лікування 21 пацієнта, у яких цукровий діабет ускладнився гнійно-некро- тичним ураженням стопи. Чоловіків було 12 , жінок 9 в віці від 47 до 73 років, медіана 63 роки, інтерквартильний розмах (IKP) 13 років. Індекс маси тіла (IMT) від 23,4 до 43,9 кг/ $\mathrm{cm}^{2}$, медіана

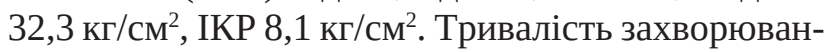
ня на цукровий діабет становила від 1 року до 33 років, медіана 10 років, IKP 9 років. Для корекції глікемії таблетовані препарати отримували 6 пацієнтів, парентерально вводили інсулін 15 хворим.

В термін від 1 місяця до 11 років перед виконанням ілеодуоденопластики 3 приводу гнійно-некротичного ураження стопи 11 пацієнтів були оперовані, один раз - 7 пацієнтів, два рази -2, чотири рази -2.

Результати досліджень та їх обговорення. Гнійно-некротичне ураження стопи оцінене як наслідок ішемії у 8 пацієнтів. Підставами для такої оцінки вважали наявність болю в стопі, що змушував тримати стопу донизу і позбавляв сну (3 спостереження), сухого некрозу шкіри стопи (5), болючої рани з відсутніми грануляціями (3), звуження артерій гомілки на 70 \% просвіту і більше за даними ультразвукової доплерометрії (5) та ангіографії (2), відсутність артерій в ампутованій частині стопи за даними гістологічного дослідження одночасно з не загоєнням операційної рани (1). 
3 цих пацієнтів 2 здійснено спробу рентгенендоваскулярної дилатації гомілкових артерій, яка визнана неефективною в процесі виконання. Видалення некротизованих пальців та ділянок некрозу тканин стопи раніше проведено 3 пацієнтам, рани не загоювались.

Діабетична артроостеопатія мала місце у 9 пацієнтів, з яких 6 оперовані на попередніх етапах лікування. У всіх мало місце незагоєння рани або артроостеопатія з деструкцією суглоба.

Волога гангрена м'яких тканин стопи або прогресуюче гнійне ураження, яке не вдавалось зупинити розкриттям гнійного вогнища та антибактеріальною терапією через нечутливість збудників до препаратів, мала місце у 4 пацієнтів.

Виконання ілеодуоденопластики супроводжувалось нормалізацією глікемії і відсутністю необхідності застосування глюкозознижувальних препаратів через три тижні і в подальшому у 19 пацієнтів, потребували приймання метформіну в дозі 10002500 мг на добу 2 пацієнти. Корекція глікемії в ран- ньому післяопераційному періоді була неповною у пацієнтів з індексом маси тіла 42,3 та 43,9 кг/ $\mathrm{cm}^{2}$.

У термін 6 місяців і більше після здійснення ілеодуоденопластики жоден із пацієнтів не потребував корекції глікемії.

Прояви ішемії стопи відразу після операції пом'якшились у всіх 8 пацієнтів.

Рецидив болю через 3 та 6 місяців після здійснення ілеодуоденопластики виник у трьох пацієнтів, з них двом раніше виконувалась спроба дилатації артерій гомілки. Одному пацієнту виконана висока ампутація нижньої кінцівки, двоє померли через 8 та 10 місяців від гострого порушення кровообігу головного мозку.

Серед інших 5 пацієнтів, оперованих на тлі ішемії, у всіх відмічене стійке зникнення проявів ішемії. У одного хворого болюча рана між пальцями загоїлась, термін після операції 8 місяців. Інші 4 пацієнтів обстежені через 3-5 років після операції. Наводимо результати доплерографії одного 3 пацієнтів (табл. 1).

Таблиця 1. Зміни доплерографії артерій нижніх кінцівок через 3,5 року після ілеодуоденопластики

\begin{tabular}{|c|c|c|c|}
\hline & & 2015 p. & 2019 p. \\
\hline \multirow[t]{3}{*}{ a.femoralis com.dr. } & товщина інтима-медіа & 1,2 & $0,9-1,2$ \\
\hline & Vсист. $^{*}$ & 74 & 62 \\
\hline & Vдіаст.** & -20 & -20 \\
\hline \multirow[t]{2}{*}{ a.femoralis com. sin. } & Vсист. & 74 & 62 \\
\hline & Vдіаст. & -20 & -22 \\
\hline \multirow[t]{2}{*}{ a.femoralis superf. dr. } & Vсист. & 65 & 68 \\
\hline & Vдіаст. & -16 & -18 \\
\hline \multirow[t]{2}{*}{ a.femoralis superf. sin. } & Vсист. & 70 & 30 \\
\hline & Vдіаст. & -13 & -4 \\
\hline \multirow[t]{2}{*}{ a.poplitea dr. } & Vсист. & 56 & 52 \\
\hline & Vдіаст. & -8 & -5 \\
\hline \multirow[t]{2}{*}{ a.poplitea sin. } & Vсист. & 51 & 54 \\
\hline & Vдіаст. & -11 & -10 \\
\hline \multirow[t]{2}{*}{ a.tibialis ant. dr. } & Vсист. & 40 & 31 \\
\hline & Vдіаст. & -8 & -3 \\
\hline \multirow[t]{3}{*}{ a.tibialis ant. sin. } & Vсист. & 37 & 32 \\
\hline & Vдіаст. & +5 & -5 \\
\hline & Кровоток & колатеральний & магістральний \\
\hline \multirow[t]{3}{*}{ a.tibialis post. dr. } & Vсист. & 47 & 20 \\
\hline & Vдіаст. & -3 & -2 \\
\hline & Кровоток & колатеральний & магістральний \\
\hline \multirow[t]{3}{*}{ a.tibialis post. sin. } & Vсист. & 39 & 54 \\
\hline & Vдіаст. & +7 & -9 \\
\hline & Кровоток & колатеральний & магістральний \\
\hline
\end{tabular}

Примітки: Vсист. - швидкість кровотоку в систолу, см/с,

** Vдіаст. - швидкість кровотоку в діастолу, см/с. 
Отже, виконання ілеодуоденопластики зумовило зменшення клінічних проявів ішемії у 5 з 8 пацієнтів зі збереженням ефекту впродовж 5 років. Виконання високої ампутації виявилось необхідним тільки у пацієнтів з проявами критичної ішемії стопи.

На тлі хронічного остеомієліту, гнійної нориці та виразки ілеодуоденопластику виконали у 6 хворих з діабетичною артроостеопатією, на тлі гострого гнійного ураження суглобів та м'яких тканин у 3 хворих. В разі гострого запалення здійснення ілеодуоденопластики вважали вимушеним заходом як єдиний спосіб уникнення високої ампутації нижньої кінцівки на тлі метаболічного синдрому, який не піддавався стабілізації іншими способами лікування. Втручання виконували на тлі тимчасового згасання гнійного запалення, досягнутого впродовж 9-20 діб шляхом санації гнійного вогнища та призначення антибіотиків відповідно до чутливості мікроорганізмів.

У всіх пацієнтів вже на наступний день після здійснення ілеодуоденопластики перебіг гнійного запалення обривався, гнійні рани загоювались впродовж 3 тижнів. Наводимо спостереження.

Пацієнт 3., чоловік, 56 років, страждав на хронічний остеомієліт IV-V кісток плесни лівої стопи, який виник після розкриття флегмони стопи на тлі гострої артроостеопатії. Сформувалась та існувала впродовж 4 років хронічна гнійна нориця (рис. 1).

За даними рентгенологічного дослідження встановлені лізис IV та V плесно-фалангових суглобів лівої стопи (рис. 2).

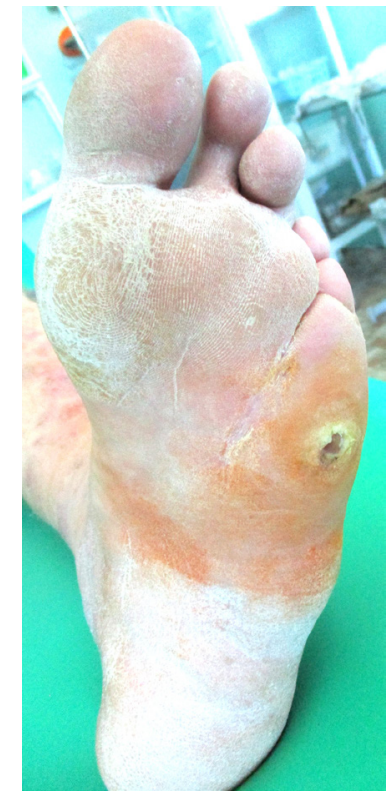

Рис. 1. Гнійна нориця, стопа пацієнта 3.

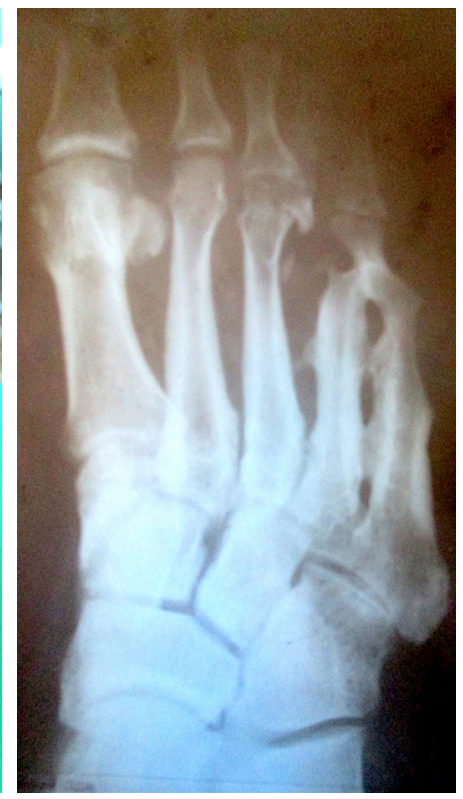

Рис. 2. Лізис IV та V плесно-фалангового з'єднання пацієнта 3.
Через 3 місяці після виконання ілеодуоденопластики нориця загоїлась (рис. 3).

За даними рентгенологічного дослідження вогнища лізису та руйнації кісток і суглобів зникали, структура кісток стабілізувалась (рис. 4).

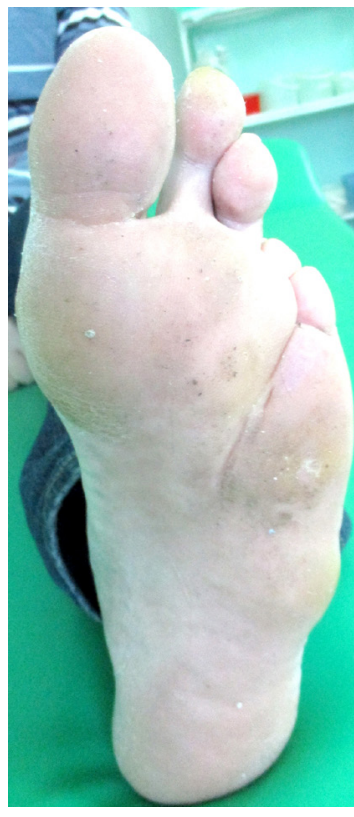

Рис. 3. Стопа пацієнта 3. через 3 місяці після виконання ілеодуоденопластики.

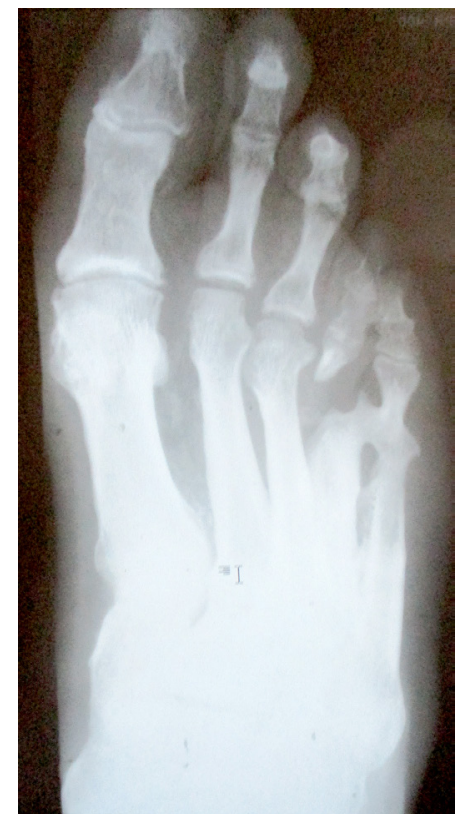

Рис. 4. Стабілізація структури кісток стопи пацієнта 3. через 3 місяці після виконання ілеодуоденопластики.
В 3 спостереженнях на тлі деструктивно змінених внаслідок гнійного запалення кісток та м'яких тканин виник сухий некроз пальців, в термін 1,5-3 місяці виконане їх видалення з неускладненим загоєнням операційної рани.

Ниркова недостатність на час виконання ілеодуоденопластики була у 2 пацієнтів, обоє не лікувались. Один помер через 1 рік від уремії, у іншого на тлі нелікованої ниркової недостатності та уремії через 4 роки виникла виразка підошви переднього відділу стопи, здійснена резекція переднього відділу стопи, рана загоїлась без ускладнень.

У 5 пацієнтів в термін 2-8 років, ще у 2 пацієнтів в термін спостереження менше 1 року рецидиву ураження суглобів і кісток немає.

У жодного з пацієнтів не виникла необхідність виконання високої ампутації нижньої кінцівки.

Таким чином, виконання ілеодуоденопластики супроводжувалось усуненням діабетичної артроостеопатії у всіх пацієнтів.

Прогресування гнійного запалення м'яких тканин стопи та гомілки, яке не вдавалось зупинити антибактеріальною терапією, призначеною відповідно до чутливості мікроорганізмів, та виконанням дренування гнояка або малої ампутації, зму- 
сило до виконання ілеодуоденопластики як останнього засобу для збереження опороздатної стопи у 4 пацієнтів.

Так само, як і у пацієнтів з діабетичною артроостеопатією, виконання ілеодуоденопластики зумовило переривання гострого гнійного запалення, очищення та загоєння ран в усіх спостереженнях. Рецидив гнійно-некротичного ураження стопи у пацієнтів не спостерігали.

В рандомізованих та мета-дослідженнях, проведених впродовж останніх 10 років, визнана і постійно підтверджується відсутність переваги в призначенні будь-якого виду антибактеріальної терапії для досягнення успіху в лікуванні гнійної інфекції у хворих на цукровий діабет 2 типу [6, 7].

Поєднане застосування системного та місцевого антибактеріального лікування покращує загальний результат, але не дозволяє гарантовано досягти зупинки гнійного ураження [6].

Таке визнання свідчить, що успіх в лікуванні діабетичної стопи слід шукати не тільки в удосконаленні боротьби зі збудником гнійного запалення, але і в пошуку і усуненні інших чинників, які лежать в основі виникнення ураження.

На користь пошуку причин стійкості до існуючого лікування гнійно-некротичного ураження стопи у хворих на цукровий діабет 2 типу свідчить пропозиція до застосування для діагностики біопсії кістки та позитронно-емісійної томографії [8, 9].

Відсутність чітко визнаних ознак патологічних змін, що зумовлює застосування складних технологій, є свідченням багатопричинності ураження, а також того, що дійсні чинники захворювання поки що не встановлені.

Отримані результати створюють враження про можливість нового підходу до лікування гнійно-некротичного ураження стопи у хворих на цукровий діабет 2 типу. Завдяки виконанню ілеодуоденопластики у всіх спостереженнях припинилось прогресування гнійно-деструктивних змін тканин стопи. Оскільки ці зміни відбувались вже в перші дні після виконання операції, слід вважати їх наслідком зміни процесів метаболізму, які викликані хірургічним втручанням та переміщенням секреторно активних зон кишечника.

\section{СПИСОК ЛІТЕРАТУРИ}

1. Antibiotic therapy of diabetic foot infections: A systematic review of randomized controlled trials / H. Tchero, P. Kangambega, L. Noubou [et al.] // Wound Repair Regen. - 2018. Vol. 26 (5). - P. 381-391. doi: 10.1111/wrr.12649.

2. The care of transmetatarsal amputation in diabetic foot gangrene / M. Ammendola, R. Sacco, L. Butrico [et al.] // Int. Wound J. -
3 цим припущенням узгоджується нормалізація глікемії, яка настає в перші дні після виконання ілеодуоденопластики. Як і зупинка перебігу гнійного запалення, ці зміни відбуваються на тлі практично незмінної маси тіла пацієнта. Тому більше підстав вважати спостережений результат наслідком змін регуляції, ніж мальабсорбції.

Наведені дані відкривають можливості для нового розуміння механізмів нечутливості до антибактеріальної терапії гнійних уражень у хворих на цукровий діабет 2 типу, так само, як для можливостей щодо відновлення здатності тканин до загоєння.

Це відповідає поглядам інших дослідників, які висловлюються на користь пошуку способів ефективної стимуляції регенерації тканин [10].

Висновки. 1. Виконання ілеодуоденопластики припиняє прогресування ішемії, артроостеопатії та гнійного запалення як основних чинників деструктивного ураження стопи у хворих на цукровий діабет.

2. Ефект ілеодуоденопластики щодо діабетичної стопи проявляється в ранні терміни після здійснення втручання, що свідчить більше про регуляторний, ніж мальабсорбційний вплив операції.

3. Вплив виконання ілеодуоденопластики перевищує дієвість інших способів лікування гнійно-некротичного ураження стопи у хворих на цукровий діабет 2 типу.

Перспективи подальших досліджень. Представлений матеріал грунтується на результатах лікування порівняно невеликої кількості пацієнтів. Накопичення клінічного досвіду, без сумніву, супроводжуватиметься виявленням особливостей перебігу різних видів гнійно-некротичного ураження стопи після виконання ілеодуоденопластики у пацієнтів із різним ступенем деструкції тканин.

Як $з$ наукової, так і з практичної точок зору, важлива детальна оцінка особливостей реакції проінсулінових та контраінсулінових гормонів, змін чутливості мікроорганізмів до антибіотиків, можливостей поєднаного застосування ілеодуоденопластики з стентуванням артерій у таких пацієнтів.

2017. - Vol. 14 (1). - P. 9-15. doi: 10.1111/iwj.12682.

3. Borkosky S. L. Incidence of re-amputation following partial first ray amputation associated with diabetes mellitus and peripheral sensory neuropathy: a systematic review / S. L. Borkosky, T. S. Roukis // Diabet Foot Ankle. - 2012. - Vol. 3. doi: 10.3402/dfa.v3i0.12169. 
4. Classification systems for lower extremity amputation prediction in subjects with active diabetic foot ulcer: a systematic review and meta-analysis / M. Monteiro-Soares, D. MartinsMendes, A. Vaz-Carneiro [et al.] // Diabetes Metab. Res. Rev. 2014. - Vol. 30 (7). - P. 610-622. doi: 10.1002/dmrr.2535.

5. International Working Group on the Diabetic Foot. Interventions in the management of infection in the foot in diabetes: a systematic review / E. J. Peters, B. A. Lipsky, J. Aragón-Sánchez [et al.] // Diabetes Metab. Res. Rev. - 2016. - Vol. 32, Suppl. 1. - P. 145153. doi: 10.1002/dmrr.2706.

6. Topical antimicrobial agents for treating foot ulcers in people with diabetes / J. C. Dumville, B. A. Lipsky, C. Hoey [et al.] // Cochrane Database Syst Rev. - 2017. - Vol. 14 (6). P. CD011038. doi: 10.1002/14651858.CD011038.pub2.

7. Systemic antibiotics for treating diabetic foot infections / A. Selva Olid, I. Solà, L.A. Barajas-Nava [et al.] // Cochrane
Database Syst. Rev. - 2015. - Vol. 4 (9). doi: 10.1002/14651858. CD009061.pub2.

8. Diagnostic accuracy of probe to bone to detect osteomyelitis in the diabetic foot: A systematic review / K. Lam, S. A. van Asten, T. Nguyen [et al.] // Clin. Infect. Dis. - 2016. - Vol. 1; 63 (7). P. 944-948. doi: 10.1093/cid/ciw445.

9. Diagnostic performance of Fluorine-18-Fluorodeoxyglucose positron emission tomography for the diagnosis of osteomyelitis related to diabetic foot: a systematic review and a metaanalysis / G. Treglia, R. Sadeghi, S. Annunziata [et al.] // Foot (Edinb). - 2013. - Vol. 23 (4). - P. 140-148. doi: 10.1016/j. foot.2013.07.002.

10. Andrews K. L. Wound management of chronic diabetic foot ulcers: from the basics to regenerative medicine / K. L. Andrews, M. T. Houdek, L. J. Kiemele // Prosthet. Orthot. Int. - 2015. Vol. 39 (1). - P. 29-39. doi: 10.1177/0309364614534296.

\section{REFERENCES}

1. Tchero, H., Kangambega, P., Noubou, L., Becsangele, B., Fluieraru, S., \& Teot, L. (2018). Antibiotic therapy of diabetic foot infections: A systematic review of randomized controlled trials. Wound Repair Regen, 26 (5), 381-391. doi: 10.1111/wrr.12649. 2. Ammendola, M., Sacco, R., Butrico, L., Sammarco, G., de Franciscis, S., \& Serra, R. (2017). The care of transmetatarsal amputation in diabetic foot gangrene. Int. Wound J., 14 (1), 9-15. doi: 10.1111/iwj.12682.

3. Borkosky, S.L., \& Roukis, T.S. (2012). Incidence of reamputation following partial first ray amputation associated with diabetes mellitus and peripheral sensory neuropathy: a systematic review. Diabet Foot Ankle, 3. doi: 10.3402/dfa.v3i0.12169.

4. Monteiro-Soares, M., Martins-Mendes, D., Vaz-Carneiro, A., Sampaio, S., \& Dinis-Ribeiro, M. (2014). Classification systems for lower extremity amputation prediction in subjects with active diabetic foot ulcer: a systematic review and meta-analysis. Diabetes Metab. Res. Rev., 30 (7), 610-22. doi: 10.1002/dmrr.2535.

5. Peters, E.J., Lipsky, B.A., Aragón-Sánchez, J., Boyko, E.J., Diggle, M., Embil, J.M., ... \& Jeffcoate, W.J. (2016). International Working Group on the Diabetic Foot. Interventions in the management of infection in the foot in diabetes: a systematic review. Diabetes Metab. Res. Rev., 32, 1, 145-153. doi: 10.1002/dmrr.2706.
6. Dumville, J.C., Lipsky, B.A., Hoey, C., Cruciani, M., Fiscon, M., \& Xia, J. (2017). Topical antimicrobial agents for treating foot ulcers in people with diabetes. Cochrane Database Syst. Rev., 14, 6, CD011038. doi: 10.1002/14651858.CD011038.pub2. 7. Selva Olid, A., Solà, I., Barajas-Nava, L.A., Gianneo, O.D., Bonfill Cosp, X., \& Lipsky, B.A. (2015). Systemic antibiotics for treating diabetic foot infections. Cochrane Database Syst. Rev., 4, (9), CD009061. doi: 10.1002/14651858.CD009061.pub2.

8. Lam, K., van Asten, S.A., Nguyen, T., La Fontaine, J., \& Lavery, L.A. (2016). Diagnostic accuracy of probe to bone to detect osteomyelitis in the diabetic foot: A systematic review. Clin. Infect. Dis., 1, 63 (7), 944-948. doi: 10.1093/cid/ciw445.

9. Treglia, G., Sadeghi, R., Annunziata, S., Zakavi, S.R., Caldarella, C., Muoio, B., ... \& Giovanella, L. (2013). Diagnostic performance of Fluorine-18-Fluorodeoxyglucose positron emission tomography for the diagnosis of osteomyelitis related to diabetic foot: a systematic review and a meta-analysis. Foot (Edinb), 23 (4), 140-148. doi: 10.1016/j.foot.2013.07.002.

10. Andrews, K.L., Houdek, M.T., \& Kiemele, L.J. (2015). Wound management of chronic diabetic foot ulcers: from the basics to regenerative medicine. Prosthet. Orthot. Int., 39 (1), 2939. doi: 10.1177/0309364614534296.

S. E. PODPRYATOV ${ }^{1,2}$, S. S. PODPRIATOV ${ }^{1,2}$, V. V. SALATA ${ }^{1,2}$, V. V. IVAHA ${ }^{1,2}$, I. O. BIELOUSOV ${ }^{1,2}$, V. P. KORCHAK ${ }^{1,2}$, I. V. SATSIUK ${ }^{2}$

Kyiv City Center of Electric Welding Surgery ${ }^{1}$

Kyiv City Municipal Hospital No. $1^{2}$

\section{ILEODUODENOPLASTY IMPACT ON FOOT PURULENT-NECROTIC LESION IN TYPE 2 DIABETES PATIENTS}

The aim of the work: to evaluate the effect of ileoduodenoplasty on the state of purulent necrosis of the foot in patients with diabetes mellitus type 2 .

Materials and Methods. Twenty-one patients with type 2 diabetes complicated by purulent-necrotic lesions of the foot underwent a surgical intevention on intestine. Ileoduodenoplasty, the kind of duodenal elimination and ileum transposition, was performed. There were 12 


\section{ЕКСПЕРИМЕНТАЛЬНІ ДОСЛІДЖЕННЯ}

men and 9 women at the median age 63 years, interquartile range (IQR) 13 years, with median body mass index (BMI) $32.3 \mathrm{~kg} / \mathrm{cm}^{2}$, IQR $8.1 \mathrm{~kg} / \mathrm{cm}^{2}$. Median diabetes duration was 10 years with IQR of 9 years. 6 patients received tablet glucose-lowering medicine, and 15 received parenteral insulin injections.

Results and Discussion. Normoglycemia without medical correction was achieved three weeks after the ileoduodenoplasty was performed. 19 patients needed metformin intake during 2 months.

High amputation of the lower extremity was performed in 3 and 6 months after ileoduodenoplasty in 2 patients on the background of critical foot ischemia. In other patients foot arterial blood flow significantly improved. Patients with diabetic arthroseopathy and purulent foot defects did not have high amputation. In the term up to 5 years of neither hyperglycemia relapse, nor diabetic foot lesions were not observed. Ileoduodenoplasty appears to be a more effective way of treating purulent-necrotic lesions of the foot in patients with type 2 diabetes mellitus compared with other methods.

Key words: diabetes mellitus type II; ileoduodenoplasty; necrotic-purulent foot.

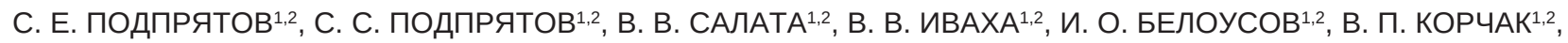
и. В. САЦЮК ${ }^{2}$

Киевский городской центр электросварочной хирургии Киевская городская клиническая больница № $1^{2}$

\section{В.ЛИЯНИЕ ИЛЕОДУОДЕНОПЛАСТИКИ НА ТЕЧЕНИЕ ГНОЙНО-НЕКРОТИЧЕСКОГО ПОРАЖЕНИЯ СТОПЫ У БОЛЬНЫХ С САХАРНЫМ ДИАБЕТОМ 2 ТИПА}

Цель работы: оценить влияние выполнения илеодуоденопластики на состояние течения гнойно-некротического поражения стопы у больных сахарным диабетом 2 типа.

Материалы и методы. Проведен анализ результатов выполнения операции на кишечнике у 21 пациента с сахарным диабетом 2 типа, осложненным гнойно-некротическим поражением стопы. Илеодуоденопластика является вариантом выключения двенадцатиперстной кишки из пассажа пищи в сочетании с перемещением подвздошной кишки. Мужчин было 12, женщин 9 ,

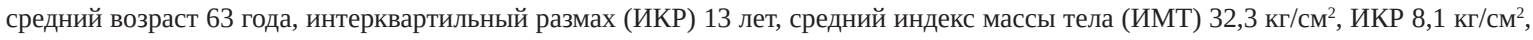
средняя длительность течения сахарного диабета 10 лет, ИКР 9 лет. Получали таблетированные глюкозопонижающие препараты 6 пациентов, парентерально вводили инсулин 15 больным.

Результаты исследований и их обсуждение. Нормогликемия без медикаментозной коррекции была достигнута в течение 3 недель после выполнения илеодуоденопластики у 19 пациентов, нуждались в приеме метформина в течение еще 2 месяцев 2 больных.

Высокая ампутация нижней конечности через 3 и 6 месяцев произведена 2 пациентам, которым илеодуоденопластика выполнена на фоне критической ишемии стопы. В остальных наблюдениях кровоток по артериям стопы существенно улучшился. На фоне артроостеопатии и гнойного поражения высокую ампутацию нижней конечности не выполняли.

В течение до 5 лет после осуществления илеодуоденопластики рецидив гипергликемии и гнойно-некротического диабетического поражения стопы не наблюдали.

Результаты выполнения илеодуоденопластики представляются более эффективными по сравнению с другими способами лечения гнойно-некротического поражения стопы у больных с сахарным диабетом 2 типа.

Ключевые слова: сахарный диабет 2 типа; илеодуоденопластика; гнойно-некротическое поражение стопы. 